\title{
$\lambda N$ Antitermination System: Functional Analysis of Phage Interactions with the Host NusA Protein
}

\author{
Alan T. Schauer ${ }^{1} \uparrow$, Debra L. Carver ${ }^{1}$, Bradley Bigelow $^{1}$ \\ L. S. Baron ${ }^{2}$ and David I. Friedman ${ }^{1} \ddagger$ \\ ${ }^{1}$ Department of Microbiology and Immunology \\ The University of Michigan Medical School, Ann Arbor, MI 48109, U.S.A. \\ ${ }^{2}$ Department of Bacterial Immunology, Walter Reed Army Institute of Research \\ Walter Reed Army Medical Center, Washington, DC 20307, U.S.A.
}

(Received 17 March 1986, and in revised form 22 October 1986)

\begin{abstract}
Coliphage $\lambda$ gene expression is regulated temporally by systems of termination and antitermination of transcription. The $\lambda$-encoded $N$ protein $(\mathrm{pN})$ acting with host factors (Nus) at sites (nut) located downstream from early promoters is the first of these systems to operate during phage development. We report observations on some of the components of this complex system that, in part, address the way in which these elements interact to render RNA polymerase termination-resistant. (1) The isolation of a conditionally lethal cold-sensitive nusA mutation demonstrates that NusA is essential for bacterial growth. (2) The effect on $\lambda$ growth in a host in which the Salmonella NusA protein is overproduced suggests that NusA is essential for $N$-mediated antitermination in phage $\lambda$. (3) A truncated NusA product, representing only the amino two-thirds of the native protein, is active for both bacterial growth and $\mathrm{pN}$ action, indicating that the carboxy end of the molecule may not be a functionally important region. (4) $\lambda \mathrm{pN}$ can function with the heterologous nut region from Salmonella typhimurium phage P22 when $\lambda \mathrm{pN}$ is overproduced, demonstrating that $\lambda \mathrm{pN}$ can function with the nut regions of other lambdoid phages. (5) A single base-pair change in the $\lambda n u t \mathrm{R}$ box $\mathrm{A}$ sequence that was selected to permit a $\lambda$ derivative to utilize the Salmonella NusA protein restores $\lambda$ growth in the Escherichia coli nusAl host.
\end{abstract}

\section{Introduction}

Temporal regulation of coliphage $\lambda$ gene expression is imposed primarily by a system of transcription termination and antitermination (for a review, see Friedman \& Gottesman, 1983). Antitermination of the early $\lambda$ transcripts (Roberts, 1969 ) results from the action of a small, highly basic phage protein, $p N$ (Franklin \& Bennett, 1979; Greenblatt \& Li, 1982). Details of $\mathrm{pN}$ antitermination are shown diagrammatically in Figure 1 and are reviewed by Friedman \& Gottesman (1983). In brief, transcription initiating at the early $\lambda$ promoters, $p \mathrm{~L}$ and $p \mathrm{R}$, becomes terminationresistant when $\mathrm{pN}$ and bacterial factors (Nus proteins) act at sites (nut) to alter RNA polymerase activity. Subsequent transcription downstream

+ Present address: Harvard University, Biological Laboratories, 16 Divinity Avenue, Cambridge, MA 02138 . U.S.A.

$\ddagger$ Author to whom all correspondence should be sent. from nut becomes resistant to many, but not all, transcription termination signals. $\lambda$ derivatives that are $N$-independent have been isolated: one class of these mutants ( $\lambda$ nin) is deleted for the $t \mathrm{R} 2$ and $t \mathrm{R} 3$ termination regions (Court \& Sato, 1969; Fiandt et al., 1971; K. Leason \& D. I. Friedman, unpublished results; M. Gottesman, personal communication). The products of tive E'scherichia coli genes have been identified as Nus factors (Friedman \& Gottesman, 1983).

The nusA gene maps at minute 69 on the $E$. coli chromosome and was identified in studies employing an $E$. coli $\mathrm{K} 12$ host with the nusAl mutation (Friedman, 1971; Friedman \& Baron, 1974). This mutation fails to support $\lambda$ growth at $42^{\circ} \mathrm{C}$, because it results in a severe reduction in $\mathrm{pN}$ action. At lower temperatures wild-type $\lambda$ grows well, even though there is reduced $\mathrm{pN}$ activity (Friedman et al., 1973a). The nusA gene encodes a $54,000 M_{\mathrm{r}}$ protein (determined from sequence; Ishii et al., 1984; Y. Nakamura, personal communication) that binds both to RNA polymerase and to $\mathrm{pN}$ 679 


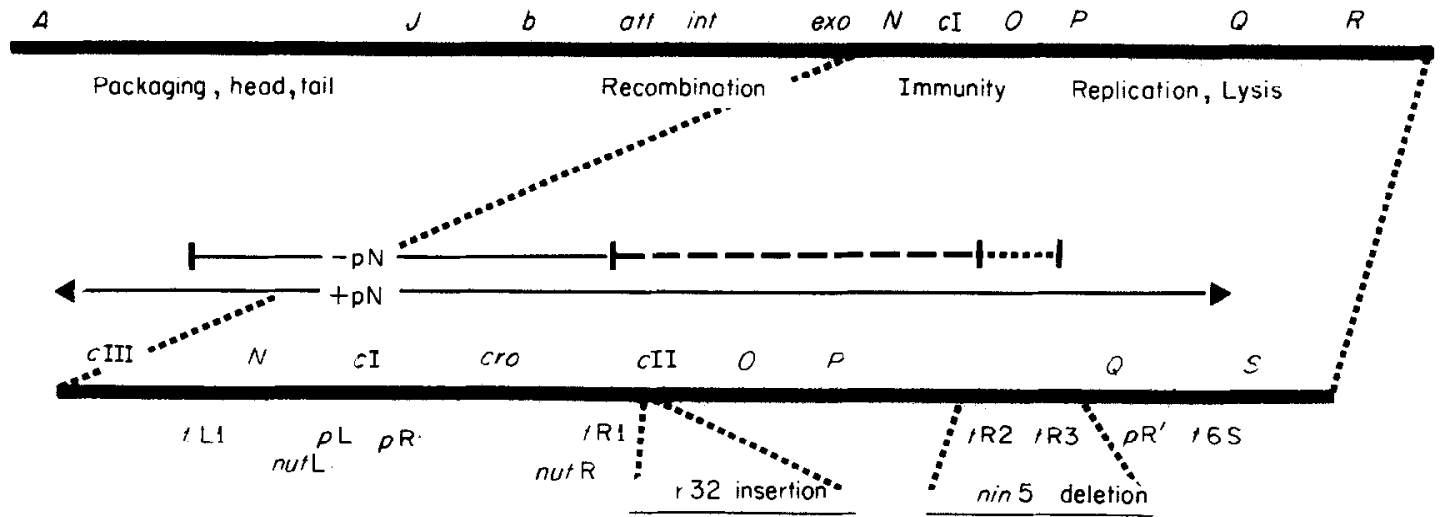

Figure 1. Lambda and transcription antitermination. The linear phage chromosome depicted in the upper part of the Figure is drawn approximately to scale (Szybalski \& Szybalski, 1979). Only some genes are shown. The bottom diagram is a genetic map of the bacteriophage $\lambda$ immunity and replication regions (not to scalc). The repressor gene, $c \mathbf{I}$, lies between the 2 early promoters, $p \mathrm{~L}$ and $p \mathrm{R}$, and its protein product represses this transcription during lysogeny by binding to the operators $o \mathrm{~L}$ and $o \mathrm{R}$. During execution of the lytic program, transcripts terminate at $t \mathrm{~L} 1$ on the left, partially at $t \mathrm{RI}$ on the right, and more completely at $t \mathrm{~K} 2$ and $t \mathrm{R} 3$. Once $\mathrm{N}$ protein has achieved a sufficient concentration, it acts at the $n u t \mathrm{~L}$ and $n u t \mathrm{R}$ regions. Action at $n u t \mathrm{R}$ results in transcription that proceeds through the terminators and into $Q$, the gene encoding the late transcription antiterminator. $\mathrm{p} Q$ action permits transcripts to reach the distal morphogenic genes. Also shown is the r32-IS2 insertion in the $\lambda c \mathrm{II}$ gene as well as the nin5 deletion that relieves $\lambda$ of $N$-dependency by removal of the $t \mathrm{R} 2$ and $t \mathrm{R} 3$ terminators. The primary transcripts that are made in the presence or absence of $\mathrm{pN}$ are depicted by the lines just above the bottom diagram.

(Greenblatt \& Li, 1981), although typically it runs at an apparent molecular weight of 69,000 on polyacrylamide gels. In a variety of transcriptional systems. NusA enhances the pausing of RNA polymerase as well as transcription termination and antitermination (Greenblatt et al., 1981; Kingston \& Chamberlin, 1981; Farnham et al., 1982; Lau et al. 1982; Simons \& Kleckner, 1983; Fisher \& Yanofsky, 1983; Schmidt \& Chamberlin, 1984; Peacock et al., 1985: Sharrock et al., 1985).

The construction of a viable $E$. coli-Salmonella typhimurium hybrid host showed that the Salmonella nusA gene, when expressed in $E$. coli can supply any NusA activity that is essential for E. coli growth (Baron et al., 1970; Friedman \& Baron, 1974). This hybrid bacterium carries a small Salmonella DNA substitution in the $E$. coli chromosome; it expresses the wild-type Salmonella $n u s \mathrm{~A}$ gene $\left(n u s \mathrm{~A}^{\mathrm{Sal}}\right)$ instead of the $E$. coli gene. The NusA $^{\text {Sal }}$ protein does not support growth of wildtype $\lambda$. As in the case of the nusAl mutant, the hybrid bacterium (hereafter called the $\mathrm{NusA}^{\text {Sal }}$ host) does not support the growth of $N$-dependent $\lambda$ derivatives, but supports the growth of $N$-independent phages such as $\lambda$ nin.

Nakamura et al. (1986) have isolated mutations in $n u s \mathrm{~A}$ that result in the death of the bacterium at high temperature. These results suggest that nus $\mathrm{A}$ is an essential function for growth at high temperature. $\Lambda$ number of experiments demonstrate a difference in the requirement for Nus factors at high and low temperature in the $\mathrm{pN}$-mediated antitermination reaction (Friedman \& Gottesman, 1983), raising the question of whether NusA protein is also required for bacterial growth at low temperature.
The $\lambda$ nut regions, where $\mathrm{pN}$ and Nus factors alter RNA polymerase activity, are located downstream from the $p \mathrm{~L}$ and $p \mathrm{R}$ promoters, but upstream from the terminators (Fig. 1; Friedman et al., 1973b; Adhya et al., 1974; Franklin, 1974; Salstrom \& Szybalski, 1978). Mutational analyses have demonstrated functional roles for two sequences in the nut region: the nut stem-loop structure (a 17base-pair sequence also referred to as $b o x \mathrm{~B}$ ), and a seven base-pair sequence called boxA. The first nut mutations were identified in the box $\mathrm{B}$ region (Salstron \& Szybalski, 1978). Subsequently, two types of mutation in boxA were identified: (1) the boxAl allele that enables a $\lambda$ derivative to use NusA $^{\text {Sal }}$ (Friedman \& Olson, 1983); and (2) two other changes in box $\mathrm{A}$ that reduced $\mathrm{pN}$-mediated antitermination, demonstrating that an intact boxA sequence is required (at least at 40 to $42^{\circ} \mathrm{C}$ ) for the $\mathrm{pN}$ reaction (Olson et al., 1984; Peltz et al., 1985). Identification of the $\mathrm{A}$ to $\mathrm{T}$ transversion in box $\mathrm{Al}$ led to the suggestion that boxA could be a NusA target site (Friedman \& Olson, 1983).

The boxAl mutation was obtained by selecting for a $\lambda$ mutant that could grow in the NusA ${ }^{\mathrm{Sal}}$ host. A two-stage selection procedure was devised, based upon the results of studies in vivo and in vitro on $\mathrm{pN}$ interaction with NusA. A $\lambda$ derivative was employed that has an $N$ mutation (punAl) that permits phage growth in an $E$. coli nusAl mutant at $42^{\circ} \mathrm{C}$. It was assumed that punAl results in the expression of a more active $\mathrm{pN}$. The phage also has an IS2 element (the r32 insertion) located immediately downstream from nutR (Fig. 1; Brachet et al., 1970; Tomich \& Friedman, 1977). The strong $p$-dependent termination signal contributed by r32-IS2 (de Crombrugghe et al., 
1973) was necessary to eliminate other classes of mutations that could make $\lambda$ growth $N$-independent (discussed by Salstrom \& Szybalski, 1978). The first step in the mutant selection yielded a phage that made a tiny plaque on the NusA ${ }^{\mathrm{Sal}}$ host at $37^{\circ} \mathrm{C}$. This phage carries a second mutation in $N$ : punAl33 (originally called pun $\mathrm{A}^{*}$ ).

The $\lambda$ punAl,133 phage was used in the second round of selection to generate a mutant that forms normal-sized plaques at $42^{\circ} \mathrm{C}$ on the nus $\mathrm{A}^{\text {Sal }}$ host; the mutation responsible for this phenotype was mapped to the $n u t \mathrm{R}$ region. DNA sequencing identified the responsible change in the box $\mathrm{A}$ region: a single base-pair transversion resulted in the box $\mathrm{A}$ sequence $5^{\prime}$-CGCTCTTT compared to the wild-type CGCTCTTA. This change had been predicted on the basis of the knowledge that other lambdoid $\mathrm{pN}$-like proteins that are active with NusA ${ }^{\text {Sal }}$ (expressed by phages P22 and 21) have the three $T$ residucs at the $3^{\prime}$ end of their boxA sequences (Friedman \& Olson, 1983 ).

This paper reports the results of a genetic dissection of $\lambda$ punAl,133 box Al; the $N$ (punA) mutations and $n u t \mathrm{R}(b \circ x \mathrm{~A})$ mutation were separated from each other and studied independently. We have found that the mutant $\mathrm{pN}$ protein and the altered box $\mathrm{A}$ sequence each contribute an enhancement in phage growth, not only with the Salmonella NusA protein, but also with the $E$. coli nusAl gene product. During the course of this analysis, we also: (1) obtained a conditionally lethal $E$. coli nusA mutation; (2) cloned and overproduced $\lambda \mathrm{pN}$ protein; and (3) cloned and overproduced Salmonella NusA protein. The results of these experiments prove that NusA protein is essential for antitermination and are consistent with the idea that box $\mathrm{A}$ might be a NusA recognition signal.

\section{Materials and Methods}

(a) Bacteria, phage and plasmids

Bacteria, phage and plasmid construets are listed in Table 1

\section{(b) Genetic techniques}

Media and basic genetic methods were as described (Miller \& Friedman, 1980; Miller et al., 1980). Mutagenesis with a mutD5 $E$. coli strain was carried out as described by Friedman \& Olson (1983).

\section{(c) Nucleic acid techniques}

DNA preparation, restriction digests, ligations and transformations were performed essentially according to Maniatis et al. (1982).

\section{(d) Isolation of nus $A \operatorname{cs} 10$}

The directed mutagenesis method of Hong \& Ames (1971) was used. Phage Pl was grown on an E. coli host K1456 (a $n u s \mathrm{~A}^{+}$strain), that carries a $\operatorname{Tn} 5$ element in $\operatorname{argG}$. The $\operatorname{argG}$ gene is $>95 \%$ contransductable with nusA (Friedman \& Baron, 1974). The resulting Pl lysate was concentrated and treated with hydroxylamine, as described by Hong \& Ames (1971). The treated Pl lysate was used to infect $E$. coli strain K37, and kanamycinresistant $\left(\operatorname{Kan}^{t}\right)$ transductants were isolated. Two of the transductants obtained grew at $40^{\circ} \mathrm{C}$, but failed to grow at temperatures below $30^{\circ} \mathrm{C}$. One, $\mathrm{K} 1914$, was chosen for further study.

\section{(e) Construction of $\mathbf{N}$ clones}

DNA fragments containing the $N$ genes of $\lambda c$ I857 and $\lambda c \mathrm{I}^{-}$pun $\mathrm{Al}, 133$ r32 were purified from ayarose as

Table 1

Bacteria, phage and plasmids

\begin{tabular}{|c|c|c|}
\hline Strain & Relevant genotype & Source \\
\hline \multicolumn{3}{|c|}{ A. E. coli $K 12$} \\
\hline K37 & W3102 nus $^{+}$str $^{\mathbf{R}}$ (nus ${ }^{+}$parent) & NIH collection \\
\hline K95 & nus A 1 & This laboratory \\
\hline K450 & nusB5 & This laboratory \\
\hline K554 & $n u s C 60$ & This laboratory \\
\hline $\mathrm{K} 556$ & nusE71 & This laboratory \\
\hline Kllo2 & $n u s \mathrm{~A}^{\mathrm{Sal}}$ & This laboratory \\
\hline K1456 & $\operatorname{argG}:: \operatorname{Tn} 5$ & This work \\
\hline K1479 & nusAl nusE7l & This laboratory \\
\hline K 1863 & JM101 & $\begin{array}{l}\text { J. Messing/ } \\
\text { W. Dunnick }\end{array}$ \\
\hline K19l4 & $n u s \mathrm{~A} c s 10$ & This laboratory \\
\hline K2065 & $\mathrm{K} 1914\left(\lambda i m m 21 n u s \mathrm{~A}^{+}\right)$ & This work \\
\hline К2067 & $\mathrm{K} 1914(\lambda i m m 21 n u s \mathrm{~A} 1)$ & This work \\
\hline K2166 & $\left(\lambda[\mathrm{BAM}]_{\Lambda} N^{+} c \mathrm{I} 14[\mathrm{H} 1]_{\Delta}\right)$ & S. Adhya/D. Ward \\
\hline $\mathrm{K} 2289$ & JM83/pUC9 & BRL. Inc \\
\hline $\mathrm{K} 2415$ & recAl nusAcs 10 & This work \\
\hline $\mathrm{K} 2417$ & $\mathrm{~K} 2415 / \mathrm{pWR} 324$ & This work \\
\hline $\mathrm{K} 2423$ & $\mathrm{~K} 1863 / \mathrm{pNAS} 100$ & This work \\
\hline $\mathrm{K} 2429$ & $\mathrm{~K} 1863 / \mathrm{pNAS} 110$ & This work \\
\hline K2448 & recAl nusAl & This work \\
\hline K2449 & $\mathrm{K} 2448 / \mathrm{pWR324}$ & This work \\
\hline $\mathrm{K} 2662$ & $\mathrm{~K} 37 / \mathrm{pDPT} 429$ & D. Taylor \\
\hline $\mathrm{K} 2664$ & K37/pNAS200 & This worl \\
\hline $\mathrm{K} 2668$ & $\mathrm{~K} 37 / \mathrm{pNAS} 150$ & This work \\
\hline K2719 & K1863/mp9-NpunA 1,133 & This work \\
\hline K2898 & $\mathrm{K} 1914 / \mathrm{pNAS} 1000$ & This work \\
\hline K3223 & K $1102 / \mathrm{pNAS} 1000$ & This work \\
\hline
\end{tabular}

\begin{tabular}{|c|c|}
\hline (Kenotype & Source \\
\hline \multicolumn{2}{|l|}{ B. Phage } \\
\hline$\lambda<1857$ & NIH collection \\
\hline iamAll & NIH collection \\
\hline$\lambda \mathrm{amR5}$ & NIH collection \\
\hline $\operatorname{iam} Q 73,501$ & NIH tollection \\
\hline ibio256sex & NIH collection \\
\hline abio 256 sex nin 5 & This laboratory \\
\hline ipunAl & This laboratory \\
\hline$\lambda c 160$ & NIH collection \\
\hline inins & NIH collection \\
\hline $21059 \arg \left({ }^{\mathrm{Sal}} n n k \mathrm{~A}^{\mathrm{Sa} !}\right.$ & This work \\
\hline$\lambda . \mathrm{r} 32$ & $\begin{array}{l}\text { This laboratory; made from } \\
\lambda N \text { am } 7,53 \text { r } 32 \text { from } W . \text { Syybalski }\end{array}$ \\
\hline$\lambda \mathrm{r} 32$ punAl & This laboratory \\
\hline$\lambda \mathrm{r} 32$ рunA1,133 & This laboratory \\
\hline$\lambda \mathrm{r} 32$ punAl,133 boxAl & This laboratory \\
\hline$\lambda b o x \mathrm{Al}$ & This work \\
\hline$\lambda_{\mathrm{r} 32} 3 \mathrm{box \textrm {Al }}$ & This work \\
\hline $\operatorname{\lambda imm21}$ nusA ${ }^{+} \operatorname{nin} 5$ & S. Adhya \\
\hline $\operatorname{\lambda imm21}$ nusAl nin5 & S. Adhya \\
\hline $\operatorname{\lambda imm2lnusA^{+}}$ & $\begin{array}{l}\text { This laboratory; made from } \lambda i m m 21 \\
n u s A^{+} \text {nins }\end{array}$ \\
\hline $\operatorname{\lambda imm21}$ nusAl & $\begin{array}{l}\text { This Jaboratory: made from timm2l } \\
\quad \text { nusAI nins }\end{array}$ \\
\hline$\lambda i m m \mathrm{P} 22$ l2amvll & S. Hilliker \& I). Botstein \\
\hline גimmP22 24ams4 & S. Hilliker \& D. Botstein \\
\hline
\end{tabular}


BamHI-PvuI restriction fragments of $\lambda$ DNA. These fragments were then cleaved with HaeIII and cloned into the Smal site of M13mp9 (Messing, 1983) and sequenced using the chain termination method as described by Biggin et al. (1983). Because there are HaelII sites adjacent to both the $5^{\prime}$ and $3^{\prime}$ ends of the $N$ gene, this cloning yielded a fragment with only a few bases on each side of the $N$ coding region, thus eliminating the $n u t \mathrm{~L}$ site. The presence of nut $\mathrm{L}$ on the plasmid could conceivably interfere with the cloning by causing plasmid transcripts to antiterminate, thereby leading to overproduction of a product that is toxic in large amounts. The use of HaelII also prevents translational read through into $N$ from upstream by introducing a stop codon in the lacZ frame. Clones which contained the $N$ gene in the correct orientation with respect to the lac promoter were identified by DNA sequencing.

The $\mathrm{N}^{+}$gene was transferred to both high and low copy expression vectors. Cloning into the pBR322 plasmid derivative pUC9 (Vieira \& Messing, 1982) was accomplished by cutting the M13mp9 clones with EcoRI and HindIII enzymes and transferring them into the same sites in pUC9. pUC9 is identical with M13mp9 throughout the $l a c$ and polylinker regions. The copy number of pUC9 was observed to be far above the expected values for a pBR322 derivative (data not shown); this is because the rop gene, which is involved in the control of DNA synthesis (Caesareni et al., 1982), was partially deleted during vector construction (Vieira \& Messing, 1982). pNAS150 is the multicopy plasmid encoding $\mathrm{pN}^{+}$.

The entire plac- $N$ constructions were transferred from the M13 clones to a single copy plasmid, pDPT429 (an R-factor derivative; D. Taylor, personal communication). This was accomplished by cutting the M13mp9 clones with AvaI and EcoRI endonucleases, ligating with EcoRI-cut pDPT429, filling out the unpaired EcoRI and $A v a I$ sites, and ligating again. The $\mathrm{N}^{+}$clone was named pNAS200.

\section{(f) Isolation of the Salmonella nus $A$ gene}

Earlier genetic studies demonstrated that the Salmonella arg G gene can be used as a selective marker to transfer $n u s \mathrm{~A}^{\text {sal }}$ into an $E$. coli $\arg \mathrm{G}^{-}$auxotroph (Baron et al., 1970; Friedman \& Baron, 1974). arg ${ }^{+}$transducing phage were selected from a library (constructed by R. Maurer) of Salmonella DNA cloned into $\lambda 1059$ (Karn et $a l ., 1980)$. The selection was done by mixing dilutions of the phage bank with a culture of E. coli $\mathrm{K} 12 \operatorname{argG}:: \operatorname{Tn} 5$ in $10 \mathrm{mM}-\mathrm{MgSO}_{4}$ and then plating onto M9 glucose minimal medium along with $0.1 \mathrm{ml}$ of LB (Luria-Bertani medium) broth in $2.5 \mathrm{ml}$ agarose. After 2 days, largehaloed plaques could be seen on the slightly grown bacterial lawn. These plaques appeared at the expected frequency of $2 \times 10^{-3}$. The plaques were purified under the selection conditions and were then used to make standard $\lambda$ lysates.

Phage carrying the Salmonella nusA gene were identified in the collection of argG clones by screening for complementation of the $E$. coli nusAcs 10 allele for growth at low temperature. Bacteria carrying the nusAcs 10 mutation are cold-sensitive for cell growth. The $\lambda 1059$ clones are deleted for functions essential for lysogeny, so lysogens were obtained by homologous recombination into a resident $\lambda$ prophage. Colonies were selected as $\arg \mathrm{G}^{+}$prototrophs and were purified on minimal medium at $40^{\circ} \mathrm{C}$. They were then shifted to $30^{\circ} \mathrm{C}$ to test for complementation of the cold-sensitive phenotype. Two of
$8 \mathrm{arg}^{+}$lysogens restored wild-type growth characteristics to the nusAcs 10 bacterium at $30^{\circ} \mathrm{C}$.

\section{(g) Construction of $p N A S 1000$}

One of the $\lambda 1059 \operatorname{argG}^{\mathrm{Sal}}$ nus $\mathrm{A}^{\text {Sal }}$ clones was chosen for subcloning. The phage DNA was partially digested with Sau3A under conditions that yielded overlapping fragments of an optimal size range. Fragments ranging in size from $1.5 \times 10^{3}$ to $4.0 \times 10^{3}$ base-pairs were eluted from an agarose gel and were ligated into the BamHI site of pACYC184. Because the transducing phage studies showed that nusA ${ }^{\text {Sal }}$ could complement a host that expresses the gene for the cold-sensitive NusAl0 protein, the ligated DNA was transformed into such a bacterium (K1914). The cells were grown at the permissive temperature and then were shifted to low temperature. After several hours there was good growth in the experimental culture, but not in a control culture that was transformed with recircularized vector. Samples of the culture were plated onto chloramphenicol plates (to select for transformants) at $30^{\circ} \mathrm{C}$ (to demand complementation of nusAcs 10). Resulting colonies were purified; one that was chosen for further analysis carries an insert of $2.8 \times 10^{3}$ base-pairs (pNAS1000).

\section{(h) DNA sequencing}

The chain termination method of Biggin et al. (1983) was employed with the following modifications. JM101 was grown overnight in minimal (M9) glucose medium. Two-ml tubes of LB were inoculated with 1 drop of the overnight culture, plus a single purified plaque. These were incubated at $37^{\circ} \mathrm{C}$ with shaking for $6 \mathrm{~h}$, and then $1.5 \mathrm{ml}$ of cells were pelleted in microfuge tubes for $10 \mathrm{~min}$. One $\mathrm{ml}$ of supernatant was transferred to tubes containing $200 \mu \mathrm{l}$ of $20 \%(\mathrm{w} / \mathrm{v})$ polyethylene glycol. $2.5 \mathrm{~m}-\mathrm{NaCl}$, and incubated at room temperature for 15 min. After a 10 -min microfuge spin, the supernatant was completely removed from the pellet. The pellet was resuspended in $150 \mu \mathrm{l}$ of TE buffer $(10 \mathrm{~mm}$-Tris. $\mathrm{HCl}$ ( $\mathrm{pH} \mathrm{8.0),} 1 \mathrm{mm-EDTA}$ ). $50 \mu \mathrm{l}$ of phenol were added and tubes were vortexed and microfuged for $15 \mathrm{~min}$. Then $100 \mu$ of the aqueous phase was precipitated in the presence of $300 \mu \mathrm{l}$ of ethanol and $10 \mu \mathrm{l}$ of $3 \mathrm{M}-\mathrm{NaOAc}$ $(\mathrm{pH} 5.5)$, at $70^{\circ} \mathrm{C}$. The nucleic acid was pelleted by a 15 -min spin, rinsed twice with $70 \%$ ethanol $(2 \times 4$ inin spins), dried, and resuspended in $40 \mu \mathrm{l}$ of 'TE buffer.

Following incubation of the sequencing reactions. samples were heated to $100^{\circ} \mathrm{C}$ for $5 \mathrm{~min}$, quenched on ice, and loaded onto $6 \%(\mathrm{w} / \mathrm{v})$ polyacrylamide gels containing 8 м urea, 50 mм-Tris-borate $(\mathrm{pH} 8.1), 1 \mathrm{mm-EDTA}$. One glass plate was treated with $\gamma$-methacryloxypropyltrimethoxysilane (Mallinckrodt) to permit the gel to be dried onto the plate. Gels were fixed $(10 \%(\mathrm{v} / \mathrm{v})$ acetic acid, $10 \%(\mathrm{v} / \mathrm{v})$ methanol for $20 \mathrm{~min}$ ), rinsed (water for $2 \times 10 \mathrm{~min})$ and dried $\left(80^{\circ} \mathrm{C}\right.$ for $\left.50 \mathrm{~min}\right)$ and then autoradiographed.

\section{(i) Construction of $\lambda$ box $A 1$}

We replaced the mutant $N$ gene in $\lambda$ punAl,133 boxAl with a wild-type $N$. A rec ${ }^{+}$host, K37, that carries pNAS150 $\left(N^{+}\right)$was infected with $\lambda$ punA1,133 boxA1. The resulting lysate was plated on a mixed bacterial lawn composed of $E$. coli strains K37 (nusA ${ }^{+}$) and K1102 $\left(n u s \mathrm{~A}^{\mathrm{Sal}}\right)$ in a ratio of $1: 5$. We expected that $\lambda b o x \mathrm{Al}$ would not grow on a lawn of $\mathrm{K} 1102$ at $40^{\circ} \mathrm{C}$ because earlier experiments showed that it was not possible to 
isolate single-step mutations mapping in the right operon of $\lambda \mathrm{r} 32$ punAl that would permit growth in K1102. We could screen for loss of growth on K1102 by using a mixture of bacteria, because $\lambda$ punAl,133 boxAl would grow on both hosts, thus making clear plaques at $40^{\circ} \mathrm{C}$. Phage that do not grow on K1102 (the expected phenotype of $\lambda N^{+}$box Al) plate turbid (due to unlysed $\mathrm{K} 1102$ in a K37 zone of lysis). We found turbid plaques at a frequency of $\sim 10^{-2}$, compared with $<10^{-4}$ for a control using the parent vector pUC9 alone. To prove that boxAl was the only phage mutation responsible for the phenotype of $\lambda b o x \mathrm{Al}$, a phage was constructed by crossing wild type $\lambda$ with a fully scquenced M13 clone carrying, as the only change from wild-type, the boxAl mutation.

\section{(j) Immuno-electroblotting}

Protein extracts were prepared as described by Ames \& Nikaido (1976) and subjected to electrophoresis in SDS/ polyacrylamide gel electrophoresis $(7.5 \%$ gel $)$. Transfer to nitrocellulose paper (NCP) was done essentially as described by Towbin et al. (1979). Blots were blocked with a solution of $3 \%(\mathrm{w} / \mathrm{v})$ bovine serum albumin (BSA) in TBS $(0 \cdot 5 \mathrm{~m}-\mathrm{NaCl}, 20 \mathrm{~mm}$-Tris $\cdot \mathrm{HCl}(\mathrm{pH} \mathrm{7.5}))$. The NCP was incubated with agitation overnight in rabbit antiNusA serum ( $1: 500$ dilution in $1 \%$ BSA/TBS) at room temperature. After 1 wash in water and 2 washes in TBS, the blot was then exposed to Staphylococcus aureus protein A conjugated with horseradish peroxidase ( 1 : 2000 dilution in a $1 \% \mathrm{BSA} / \mathrm{TBS}$ solution). The NCP was washed as described above and immune complexes were detected by treatment with $\mathrm{H}_{2} \mathrm{O}_{2}$ and 4-chloro-1naphthol.

For preparation of immune serum, rabbits were immunized intradermally with purified $E$. coli NusA protein emulsified in complete Freund's adjuvant and boosted by intradermal injection of NusA protein in incomplete Freund's adjuvant. Serum from all rabbits reacted positively with purified NusA protein in an enzyme-linked immunoadsorbent assay. Molecular weights were determined using Bethesda Research Laboratories' prestained protein molecular weight standards (myosin, 200,000; phosphorylase B, 97,400; bovine serum albumin, 68,000 ; ovalbumin, 43,000 ; $\alpha$-chymotrypsinogen, 25,700 ).

\section{Results}

(a) Isolation of a conditionally lethal nus $A$ mutation

To extend the characterization of the nus $A$ gene product's role in bacterial growth as well as to facilitate the cloning of the $n u s \mathrm{~A}^{\mathrm{Sal}}$ gene, we looked for conditionally lethal nusA mutations. We exploited the fact that nus $\mathrm{A}$ is located near argG (minute 69 on the $E$. coli chromosome). A Tn5 transposon, which confers resistance to the antibiotic kanamycin $\left(\operatorname{Kan}^{\mathrm{r}}\right)$, was placed in the $\arg \mathrm{G}$ gene to provide an easily selectable genetic marker. A lysate of phage $\mathbf{P l}$ grown on this host and mutagenized in vitro with hydroxylamine was used to transduce a nus $^{+}$host to Kan'. These transductants were screened for conditional lethality, i.e. failure to grow at $30^{\circ} \mathrm{C}$. We report on one mutation isolated in this manner; to simplify the discussion, we anticipated the results of the mapping studies described below and will refer to the mutation as nus Acs 10 .

$E$. coli carrying the $n u s$ Acs 10 mutation grow well above $35^{\circ} \mathrm{C}$, but are not viable at temperatures below $32^{\circ} \mathrm{C}$. The effect of the mutation on the action of $\lambda \mathrm{pN}$ (at $40^{\circ} \mathrm{C}$ ) is very different from that of nusAl; only the growth of $\lambda b i o 256 s e x$ is not supported. Abio256sex synthesizes lower levels of an altered $N$ gene product (S. Adhya, personal communication; unpublished results, this laboratory), and thus is more dependent upon normal levels of Nus proteins in order to make plaques. The failure of $\lambda$ bio 256 sex to grow at $40^{\circ} \mathrm{C}$ is due specifically to a failure in $\mathrm{pN}$ action; a derivative of $\lambda$ bio $256 \operatorname{se} x$ that also carries the nin5 deletion grows in the nus Acs 10 host (see Table '2)

Genetic mapping using phage $\mathrm{Pl}$ transduction located the mutation(s) responsible for the $\mathrm{Cs}$ and Nus phenotypes of the nusA gene. The nusA gene cotransduces with argG at a frequency of $95 \%$. In the first cross the donor was $\arg \mathrm{G}:$ : Tn 5 and carried a putative nusAcs allele. The recipient was wildtype at both the argG and nusA loci. Of the

Table 2

Effect of nus $A \operatorname{cs} 10$ on $p N$ action: efficiency of plating of phage

\begin{tabular}{|c|c|c|c|c|}
\hline \multirow[b]{2}{*}{ Phage } & \multicolumn{4}{|c|}{ Bacteria, nus allele and prophage } \\
\hline & $\begin{array}{c}\text { K1914 } \\
n u s \mathrm{~A} c s 10\end{array}$ & $\begin{array}{c}\mathrm{K} 2065 \\
n u s \mathrm{Acs} 10 \\
\lambda i m m 2 \ln n \mathrm{~A}^{\prime}\end{array}$ & $\begin{array}{c}\mathrm{K} 2067 \\
n u s \mathrm{Acs} 10 \\
\lambda i m m 2 \mathrm{lnus \textrm {Al }}\end{array}$ & $\begin{array}{c}\mathrm{K} 3767 \\
n u s^{+} \\
\lambda i m m 2 \mathrm{l} n u s \mathrm{Al}\end{array}$ \\
\hline$\hat{\lambda}$ & $0 \cdot 6$ & $0 \cdot 8$ & 0.7 & 1 \\
\hline$\lambda b i o 256 \operatorname{sex}$ & $10^{-6}$ & 0.5 & $10^{-6}$ & 1 \\
\hline$\lambda$ bio 256 sex $\operatorname{nin} 5$ & $1 \cdot 0$ & $1 \cdot 0$ & $1 \cdot 0$ & 1 \\
\hline
\end{tabular}

Bacteria were grown overnight in LB maltose, sedimented, and resuspended in $0.5 \mathrm{vol}$. $0.01 \mathrm{M}$ $\mathrm{MgSO}_{4}$. The phage were diluted and plated on TCMG plates using the indicated bacteria as lawns. Plates were incubated overnight at $40^{\circ} \mathrm{C}$. The titer of phage on each of the lawns was divided by the titer on a lawn of $\mathrm{K} 37$ (a nus $^{+}$isogenic parent) to give the efficiency of plating. The nusA transducing phages were derived from the hybrid phage $\lambda i m m 21$. The $i m m 21$ region encodes a repressor and $N$ gene product (Liedke-Kulke \& Kaiser, 1967) different from that of $\lambda$ (Friedman et al., 1973b), and thus the hybrid phage expresses a repressor and $\mathrm{pN}$ that will not have any effect on phage with the $i m m \lambda$ region. 


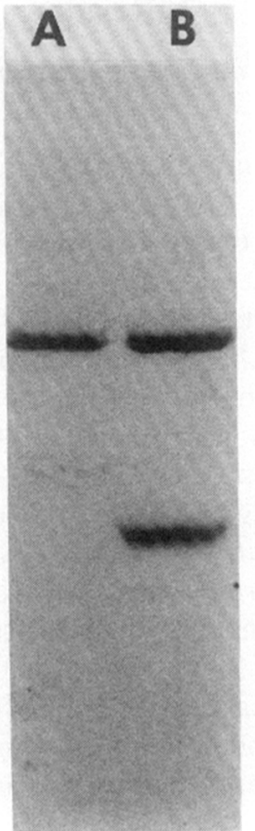

Figure 2. Immuno-electroblot of truncated NusA protein. Extracts of proteins $(\sim 10 \mathrm{mg} / \mathrm{ml})$ were made and analyzed by immuno-electroblotting as described in Materials and Methods. Lane $\mathrm{A}$ is an extract from $E$. coli strain $\mathrm{K} 37(24 \mu \mathrm{g})$; lane $\mathrm{B}$ is an extract from a $\mathrm{K} 37$ derivative carrying the pWR324 plasmid $(24 \mu \mathrm{g})$. Comparison with standards showed the upper band to be in the $69,000 M_{\mathrm{r}}$ range, while the lower band on the right is about $49,000 M_{r}$. Although NusA protein typically runs at $69,000 M_{\mathrm{r}}$ on polyacrylamide gels, the molecular weight as determined by DNA sequencing (Ishii et al., 1984; Y. Nakamura, personal communication) is $\mathbf{5 4 , 4 0 0}$ $M_{\mathrm{r}}$. Therefore the $49,000 M_{\mathrm{r}}$ truncated product may be significantly smaller.

recipients, $93 \%(138 / 148)$ that became resistant to kanamycin $\left(\mathrm{Kan}^{\mathrm{r}}\right)$ also became $\mathrm{Cs}$ and exhibited the mutant NusA phenotype as tested by $\lambda$ bio256sex growth. This mapping demonstrates that the mutation(s) responsible for the two phenotypes are either not separable or are extremely closely linked. Although the linkage with argG is completely consistent with an nusA mutation(s), it does not rule out the possibility that nusAcs 10 maps to the opposite side of $\arg G$.

The results of a second cross localize nusAcs 10 to the nusA gene. In this trunsduction, the donor was once again $\arg \mathrm{G}:: \operatorname{Tn} 5$ nus Acs 10 , while the recipient carried the nusAl mutation. The nusAl and nusAcs 10 alleles can be distinguished easily by the severity of the $\mathrm{Nus}^{-}$phenotype imposed. A host with the nusAl mutation fails to support growth of $\lambda$ wild-type as well as $\lambda$ bio256sex at $42^{\circ} \mathrm{C}$, while a host with the nusAcs 10 mutation supports growth of the former, but not the latter phage. In this cross, we found that the acquisition of the $\mathrm{Cs}$ phenotype is always accompanied by the appearance of the less restrictive Nus phenotype and the loss of the more restrictive NusAl phenotype; 90/93 $\mathrm{Kan}^{\mathrm{r}}$ transductants became Cs and also exhibited the less restrictive phenotype, while $3 / 93$ were cold-resistant and more restrictive. Therefore, the nusAcs 10 mutation is in the same gene as nusAl.

A complementation experiment was consistent with the recombination analysis. We used dimm21nus $\mathrm{A}$ transducing phages containing $12 \times 10^{3}$ base-pairs of DNA from a region of the $E$. coli genome that surrounds $n u s \mathrm{~A}$ (S. Adhya, personal communication). The results of this analysis are presented in Table 2 . Lysogens of the nusAcs 10 hosi currying a $\lambda i m m 21$ nus $\mathrm{A}^{+}$prophage support $\lambda$ bio256sex growth, while those carrying a iimm21nusAl prophage fail to support growth of $\lambda$ bio256sex at $42^{\circ} \mathrm{C}$

We also found that a truncated NusA protein complements nusAcs 10 both for growth at $30^{\circ} \mathrm{C}$ and for $\lambda \mathrm{pN}$ action (data not shown). We transformed a plasmid (pWR324) into the nusAcslo and nus $\Lambda \mathrm{l}$ hosts. The pWR324 plasmid, constructed by L. S. Baron and D. Kopecko (unpublished results), is a pBR322 derivative containing a nusA PstI fragment that includes the nusA promoter and the $5^{\prime}$ two-thirds of the nusA gene. The nature of the NusA protein expressed by the pWR324 plasmid is shown in the immuno-electroblot in Figure 2. Using antibodies prepared against purified $E$. coli NusA protein as the probe, it can be seen that, in addition to the normal NusA protein, a new cross-reacting protein of approximately $49,000 M_{\mathrm{r}}$ is synthesized in the host containing the pWR324 plasmid. All $\lambda$ derivatives tested (with the exception of $\lambda$ bio256sex) grow well at $40^{\circ} \mathrm{C}$ on a nusAl host carrying pWR324 (data not shown).

\section{(b) Overproduction of $N u s A^{\text {Sal }}$}

Two lines of evidenee led to the idea that NusA ${ }^{\text {Sal }}$ protein requires a thymine triplet in boxA (Friedman \& Olson, 1983). First, lambdoid phages that normally can function with $\mathrm{NusA}^{\mathrm{Sal}}$ (P22 and 21) have box $\mathrm{A}$ sequences with three $\mathrm{T}$ residues (e.g. TGCTCTTT in 21 nut R, CGCTCTTT in P22 nutL). Second, $\lambda$ mutants that grow on the nus $\mathrm{A}^{\text {Sal }}$ hybrid bacterium have three $T$ residues at the $3^{\prime}$ end of the box $\mathrm{A}$ sequence in nut $\mathrm{R}$. Conditions were designed to test for NusA ${ }^{\text {Sal }}$ activity in the presence of the normal $\lambda$ boxA sequence. First, we used a $\lambda$ derivative that carries box $\mathrm{A}^{+}$and the punAl and $133 N$ mutations. The mutations in $N$ convert the pN into one that functions with $\mathrm{NusA}^{\mathrm{Sal}}$ protein. Therefore, the failure of $\lambda p u n \mathrm{~A} 1,133$ to grow in the NusA ${ }^{\text {Sal }}$ host is due solely to the presence of the wild-type boxA sequence in the nut $\mathrm{R}$ region. Second, a host carrying nus $\mathrm{A}^{\text {Sal }}$ both on the chromosome and on a plasmid (pNAS1000) was constructed. Because the plasmid carrying the $n u s \mathrm{~A}^{\text {Sal }}$ gene is multi-copy, we assumed that it would overproduce NusA Sa! Figure 3 shows that this assumption was correct. 'The proteins electroblotted onto the nitrocellulose paper were probed with antibodies prepared against purified $E$. coli NusA protein. Because equal amounts of proteins 
$\begin{array}{lllllllll}1 & 2 & 3 & 4 & 5 & 6 & 7 & 8 & 9\end{array}$

Figure 3. Immuno-electroblot of NusA ${ }^{\text {Sal }}$ protein made by pNAS1000. Preparation of protein extracts, electrophoresis, immunoblotting and antigen identification were performed as outlined in Materials and Methods. Samples of each fraction containing 4,20 or $100 \mu \mathrm{g}$ were run in adjacent lanes and probed with antibodies raised against E. coli NusA protein. Lanes 1 to 3 are dilutions of an extract from K37; lanes 4 to 6 are K1102; lanes 7 to 9 are K1102/pNAS1000.

were loaded onto the gel, the fact that the intensity of the plasmid-carrying strain is greater shows that there is more NusA present in the plasmidcontaining strain.

The effect on $\lambda$ growth of NusA ${ }^{\text {Sal }}$ overproduction was determined by measuring the burst of phage following infection. As shown in Table 3, the burst of $\lambda$ punA $\mathrm{A}, 133$ is tenfold greater in the pNAS1000 plasmid-containing NusA ${ }^{\text {sal }}$ host than in the same host without the plasmid.

\section{(c) Overproduction of $p N$}

The cloning of the $\lambda N$ gene on a high copy number plasmid allowed us to address the question of $\mathrm{pN}$ specificity. For these experiments, we transferred the wild-type $N$ gene to two plasmid vectors. A pBR322 derivative, $p \mathrm{UC} 9$ (Vieira \& Messing, 1982), was chosen as a high-copy expression vector and the lac promoter $-N$ gene constructs were transferred to pDPT429, a singlecopy $R$-factor derivative (D. 'Taylor, unpublished results).

As shown in Table 4, both the single and the multi-copy recombinant plasmids complement $\lambda N^{-}$ phage for growth. The complementation is specific for $N$ : there is no complementation of $\lambda$ derivatives carrying nonsense mutations in other genes. When $N$ is expressed from the unit-copy plasmid $\lambda N^{-}$ phages are not fully complemented when compared with the effect seen in the case of $\mathrm{pN}$ expressed from a single-copy defective $\lambda$ prophage. This most likely reflects a difference in promoter strength; the plasmid-borne lac promoter is weak relative to the prophage $p \mathrm{~L}$ promoter (McClure et al., 1982). Overexpression of $N$ by the high-copy plasmid did not have any effect on growth rate when compared
Table 3

Growth of $\lambda$ in the presence of high levels of NusA $A^{\text {sal }}$ : burst size

\begin{tabular}{|c|c|c|c|}
\hline \multirow[b]{2}{*}{ Phage } & \multicolumn{3}{|c|}{ Strain, nus allele and plasmid } \\
\hline & $\begin{array}{c}\text { K37 } \\
n u s \mathbf{A}^{+} \\
(\text {E.coli })\end{array}$ & $\begin{array}{l}\mathrm{K} 1102 \\
n u s A^{\text {Sal }}\end{array}$ & $\begin{array}{c}\text { K3223 } \\
\text { nusA } \\
\text { pNAS1000 }\end{array}$ \\
\hline$\lambda$ & 422 & $\mathrm{I}$ & 1 \\
\hline$\lambda p u n \mathrm{Al}, 133$ & 228 & 17 & 290 \\
\hline$\lambda p u n \mathrm{~A} 1,133$ boxAl & 165 & 283 & 454 \\
\hline
\end{tabular}

pNAS1000 is a plasmid with the $S$. typhimurium nusA gene cloned into the tet gene of pACYC184. Bacteria were grown in LB maltose to $\sim 10^{8} / \mathrm{ml}$, sedimented and resuspended in $0.5 \mathrm{vol}$. $0.01 \mathrm{M}-\mathrm{MgSO}_{4}$. Phage were added to $0.1 \mathrm{ml}$ of bacteria at a multiplicity of $0 \cdot 1$ and adsorbed for $20 \mathrm{~min}$ at room temperature Infected bacteria were diluted into $\mathrm{LB}$ containing $10 \mathrm{~mm}-\mathrm{MgSO}_{4}$ and incubated at $37^{\circ} \mathrm{C}$. Samples were removed at zero time, treated with $\mathrm{CHCl}_{3}$ and titered on $\mathrm{K} 37\left(\right.$ nus $\left.^{+}\right)$bacteria to give the total number of phage adsorbed. The remaining bacteria were treated with $\mathrm{CHCl}_{3} 120 \mathrm{~min}$ after infection and titered. The burst is the total number of phage released divided by the total number of infected bacteria. $\lambda N^{+}$boxAl did not give a burst when grown on K3223.

with bacteria carrying pUC9 alone (data not shown).

Although earlier work had shown that $\lambda N^{-}$could grow when supplied with the $\mathrm{pN}$ of phage $\mathrm{P} 22$ (gene 24 product), there was no indication that P22 could function with $\lambda \mathrm{pN}$ (Hilliker \& Botstein, 1976 Hilliker et al., 1978). Using a su ${ }^{\circ}$ host containing the $\mathrm{pN}$-overproducing plasmid pNAS150 as a bacterial lawn, we find that when $N$ expression is maximized by adding isopropyl- $\beta$ - $\mathrm{D}$-thiogalactoside (IPTG) (fully to induce the lac promoter, which controls $N$ expression), a $\lambda$-P22 hybrid with an amber mutation in its $N$ gene (24ams4; Hilliker \&

Table 4

Complementation of $\lambda \mathrm{N}^{-}$and P22 $24^{-}$by plasmid clones of $\lambda \mathrm{N}$

\begin{tabular}{lcccc}
\hline & \multicolumn{4}{c}{ Host and plasmid } \\
\cline { 2 - 5 } Phage & K37 & K37 & K37 & K2166 \\
None & pNAS150 & pNAS200 & None \\
\hline$\lambda$ & + & + & + & + \\
$\lambda$ Nam7 & - & + & -++ & + \\
$\lambda i m m P 22$ & + & + & + & + \\
$\lambda$ immP22,24amS4 & - & + & - & - \\
\hline
\end{tabular}

Results are expressed as the presence or absence of plaques on either $\mathrm{K} 37\left(\mathrm{nus}^{+}\right)$or $\mathrm{K} 2166\left(\lambda \mathrm{I} \mathrm{I857}(\mathrm{BAM})_{\Delta} N^{+}(\mathrm{H1})_{\Delta}, n u s^{+}\right)$ containing the indicated plasmids at $40^{\circ} \mathrm{C}$ in the presence of $50 \mu \mathrm{M}$-isopropyl- $\beta$-D-thiogalactoside. K2166 provides constitutive expression of $\mathrm{N}$ protein from a defective prophage at $40^{\circ} \mathrm{C}$ pNAS150 is a very high copy plasmid (a pUC9 derivative) with $N^{\prime}$ under lac promoter control; $N^{+}$is also under lac promoter control in pNAS200, but this vector (pDPT429) exists in only 1 to 2 copies per cell. Phage derivatives with nonsense mutations in other essential genes ( $\lambda A$ amll, $\lambda \operatorname{Kam} 5, \lambda Q \mathrm{am} 73,501$ and $\lambda \mathrm{immP2212amN11)}$ did not form plaques on the hosts listed in this Table, although they did grow on nonsense-suppressing bacteria. Plasmid constructions are described in detail in Materials and Methods. 
Botstein, 1976) forms normal plaques (Table 4). Plaque formation is dependent upon the presence of IPTG, indicating that maximum lac promoter activity is required.

\section{(d) Structure of $\lambda \operatorname{pun} A 1,133 \mathrm{~N}$ gene protein}

Mapping of the punA133 mutation placed it in or near the $N$ gene (Friedman \& Olson, 1983). To determine the precise change(s) that enables $\lambda$ to function with $\operatorname{Nus} A^{\text {Sal }}$, we sequenced the $N$ gene from the $\lambda$ punA1,133 phage. Fragments containing the $N$ genes were cloned from both the mutant phage and the wild-type parent. In each case, the $N$ gene was cloned without the associated $n u t \mathrm{~L}$ region so that transcripts that initiate at the upstream lac promoter in the $\mathrm{Ml} 3 \mathrm{mp} 9$ cloning vector would not have the potential to antiterminate, and possibly to interfere with plasmid replication.

The sequence we determined for the wild-type $N$ gene agrees completely with the published sequence (Fig. 4; Franklin \& Bennett, 1979; Sanger et al., 1983). The sequence for the $N$ from the mutant phage shows only two changes from wild-type, with resulting amino acid changes: (1) the serine to arginine substitution that had previously been determined for the punAl mutation at nucleotide 125 of the $N$ gene (Franklin, 1985); and (2) a lysine to arginine replacement five codons promoterproximal to punAl (see Fig. 3). This change, unlike

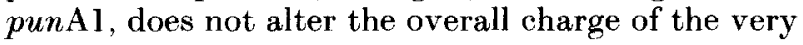
basic $\mathrm{N}$ protein.

A reconstruction experiment demonstrated that only these mutations are required, along the box Al mutation, to permit phage $\lambda$ growth in a NusA ${ }^{\text {Sal }}$ host. A $\lambda$ carrying boxAl and a wild-type $N$ (described below) was crossed with a plasmid carrying the mutant punAl,133 $N$ gene (pNAS110) or, as a control, a wild-type $N$ gene (pNAS100). Only the cross with the $N$ from $\lambda$ punAl,133 yielded recombinants that could grow in the NusA ${ }^{\mathrm{Sal}}$ host.

\section{(e) Phenotype of $\lambda \mathrm{N}^{+}$box $A 1$}

To extent our studies on the role of box $\mathrm{A}$ in $\mathrm{pN}$ action, we constructed two derivatives of $\lambda$ that carry boxAl but have a wild-type $N$ gene. This permitted direct observation of the effects of boxAl in the absence of the $N$ (punA) mutations. The first phage is essentially $\lambda$ wild-type except for the boxAl mutation. The second has an r32-IS2 insertion (see Fig. I) in addition to boxAl (see Materials and Methods for details of the constructions). The effect of the boxAl mutation on $\mathrm{pN}$ action was assessed by measuring the efficiency of plating on $E$. coli mutants. Phage growth provides a good measure of the effect of changes in the nut $\mathrm{R}$ region (including box $\mathrm{A}$ ), because all phage products that are normally essential for lytic growth, except $\mathrm{pN}$ itself, are dependent upon antitermination of transcription initiated at $p \mathrm{R}$.

As shown in Table 5, the boxAl mutation permits $\lambda$ to grow in $E$. coli hosts carrying either the nusAl or the nusE7l mutation at $42^{\circ} \mathrm{C}$. On the other hand, boxAl does not markedly improve the growth of $\lambda$ in other nus mutants, such as nusB5 (data not shown). The observation that boxAl also improves $\lambda$ growth in the nusE7l host is not surprising insofar as a number of phage and bacterial mutants selected for improving $\lambda$ growth in one mutant host (either nusAl or nusE71) also enhance $\lambda$ growth in

$$
\text { Phage } \lambda N \text { gene }
$$

ATG GAT GCA CAA ACA CGC CGC CGC GAA CGT CGC GCA GAG AAA CAG GCT CAA TGG AAA 57 Met Asp Ala Gln Thr Arg Arg Arg Glu Arg Arg Ala Glu Lys Gln Ala Gln Trp Lys

GCA GCA AAT CCC CTG TTG GTT GGG GTA AGC GCA AAA CCA GTT AAC CTC CCT ATT CTC 114 Ala Ala Asn Pro Leu Leu Val Gly Val Ser Ala Lys Pro Val Asn Leu Pro Ile Leu

$$
\text { PUIA133 PURA1 }
$$

G

TCG CTG AAT CGC AAA CCG AAA TCA CGA GTA GAA AGC GCA CTA AAT CCG ATA GAC CTT Ser Leu Asn Arg Lys Pro Lys Ser Arg Val Glu Ser Ala Leu Asn Pro Ile Asp Leu Arg Arg

ACA GTG CTG GCT GAA TAC CAC AAA CAG ATT GAA AGC AAC CTG CAA CGT ATT GAG CGC Thr Val Leu Ala Glu Tyr His Lys Gln Ile Glu Ser Asn Leu Gin Arg Ile Glu Arg

AAG AAT CAG CGC ACA TGG TAC AGC AAG CCT GGC GAA CGC GGC ATA ACA TGC AGT GGA 285 Lys Asn Gln Arg Thr Trp Tyr Ser Lys Pro Gly Glu Arg Gly Ile Thr Cys Ser Gly

CGC CAG AAA ATT AAG GGA AAA TCG ATT CCT CTT ATC TAG 324

Arg Gln Lys Ile Lys Gly Lys Ser Ile Pro Leu Ile ...

Figure 4. DNA and protein sequences of the $\lambda N$ gene showing the punAl and punAl33 mutations. The punAl mutation changes the serine to arginine; punAl33 converts the lysine to arginine. 
Table 5

Effect of box A1 mutation on growth of $\lambda$ in E. coli with mutant nus genes: efficiency of plating of phage

\begin{tabular}{|c|c|c|c|}
\hline \multirow[b]{2}{*}{ Phage } & \multicolumn{3}{|c|}{ Strain and $n u s$ allele } \\
\hline & $\begin{array}{r}\mathrm{K} 37 \\
\text { nus }^{+}\end{array}$ & $\begin{array}{c}\text { K95 } \\
n u s \mathrm{Al}\end{array}$ & $\begin{array}{c}\text { К556 } \\
n u s \mathrm{E} 7\end{array}$ \\
\hline$\lambda$ & l & $<10^{-8}$ & $<10^{-8}$ \\
\hline$\lambda \mathrm{r} 32$ & 1 & $<10^{-8}$ & $<10^{-8}$ \\
\hline$\lambda p u n \mathrm{Al}, 133$ & 1 & I & 1 \\
\hline$\lambda$ pun $\mathrm{Al}, 133$ r32 & 1 & $0 \cdot 6$ & $<10^{-4}$ \\
\hline$\lambda$ punAl 133 boxAl & 1 & 1 & 1 \\
\hline$\lambda p u n \mathrm{Al}, 133$ borAl r32 & 1 & 1 & 1 \\
\hline iboxAl & 1 & $0 \cdot 8$ & $0 \cdot 5$ \\
\hline$\lambda b o x \mathrm{Al} \mathrm{r} 32$ & 1 & $1 \cdot 2$ & $<10^{-4}$ \\
\hline$\lambda p u n \mathrm{Al}$ & 1 & 1 & 1 \\
\hline$\lambda p u n A 1$ r32 & 1 & $0 \cdot 6$ & $<10^{-4}$ \\
\hline
\end{tabular}

Bacteria were grown overnight in LB maltose. Dilutions of phage were titered on the indicated bacterial lawns on TCMG plates and incubated at $42^{\circ} \mathrm{C}$. Efficiency of plating is calculated by dividing the titer of phage observed on the indicated lawn by the titer on $\mathrm{K} 37$ (nus $^{+}$) bacteria.

the other $n u s^{-}$host (Friedman et al., 1981; Ward et $a l ., 1983$, Schauer, 1985).

A difference in the effect of boxAl on the growth of $\lambda$ in either a nusAl or nusE71 mutant is readily observed when the phage carries the r32-IS2 insertion (Brachet et al., 1970; Tomich \& Friedman, 1977 ) in addition to boxAl. IS 2 contains a strong $\rho$-dependent termination signal (de Crombrugghe et $a l ., 1973$ ) and thus is likely to impose a more stringent demand for $\mathrm{pN}$ activity at $n u t \mathrm{R}$. Table 5 shows that the boxAl r32 phage grows relatively well in the nusAl host K95, but poorly in the nusE71 host K556. Although $\lambda b o x A 1$ grows on either the nusAl or the nusE71 host at all temperatures, it does not grow in a nus Al-nusE71 double mutant, even at temperatures that are generally more permissive for $\lambda$ growth $\left(30\right.$ to $32^{\circ} \mathrm{C}$; data not shown).

\section{Discussion}

The $N$ transcription antitermination reaction of phage $\lambda$ is one of the best characterized examples of this type of gene regulation. In spite of this, it is obvious that our knowledge of the system is rudimentary. The primary question at this time is how the phage and bacterial proteins interact with each other, as well as with the nut region sequences in the phage nucleic acid. The complexity of the $N$ system has prevented the reconstruction of the reaction in a purified system in vitro, and therefore genetic analyses of host and phage mutations that influence $N$ action have provided significant insights into the antitermination mechanism.

\section{(a) NusA is essential for E. coli growth}

The isolation of a conditionally lethal mutation in the nusA gene demonstrates that NusA protein serves an essential role in $E$. coli growth. Our work with the nusAcs10 mutation complements the studies of Nakamura \& Mizusawa (1985), who showed that NusA is required for cell growth at high temperatures. 'There is reason to suspect that $\lambda$ may require different levels of NusA protein at high and low tomperatures. In particular are observations that: (1) many nus mutations impose more severe restrictions on $\mathrm{pN}$ action at higher temperatures than at lower temperatures (Friedman \& Gottesman, 1983); and (2) boxA seems to be necessary for $\mathrm{pN}$ antitermination in certain plasmid constructs at high, but not low, temperatures (Peltz et al., 1985).

The specific defect caused by the nusAcs 10 mutation has not yet been determined. However, we have isolated second-site suppressors of nusAcs 10 and characterization of these mutations should prove to be useful in determining the nature of the NusA defect in the conditionally lethal mutants. We have used both recombinational mapping and complementation studies to demonstrate that nusAcs 10 and $n u s \mathrm{Al}$ are alleles of the same gene. The fact that extensive genetic crosses failed to break the linkage between the Cs and Nus phenotypes of nusAcs 10 indicates that either the same or extremely closely linked mutations are responsible for the two phenotypes.

The truncated NusA protein $\left(49,000 \quad M_{\mathrm{r}}\right)$ expressed by the pWR324 plasmid complements the nusAcs10 mutant for growth at low temperature and restores growth of $\lambda$ bio256sex (data not shown). Preliminary results indicate that a similarly truncated $n u s \mathrm{~A}^{\text {Sal }}$ gene product can also complement nusAcs10 for cell growth (A.T. Schauer \& D. I. Friedman, unpublished results).

These findings seem to be in conflict with the results of Nakamura \& Mizusawa (1985), who report that the $49,000 \quad M_{\mathrm{r}}$ NusA protein is not effective in permitting growth of an $E$. coli nusAts mutant at the non-permissive temperature. Although we did not use their plasmid, our vector, insert and cloning scheme were the same and so we have no reason to suspect that there was any difference in the truncated protein being expressed. Perhaps the protein made in the nusAts mutant is dominant in the presence of the truncated protein, while the cold-sensitive NusA protein in our mutant is recessive. Alternatively, as discussed above, there may be a different requirement for NusA at high and low temperatures. Another difference between the nusAts and nusAcs alleles is that the coldsensitive mutation confers a nus phenotype, albeit a weak one.

Our experiments with the $49,000 \quad M_{\mathrm{r}}$ NusA protein suggest that the biological activity of NusA that is required both for $\lambda N$ action and for bacterial viability (at least at lower temperatures) is located in the amino two-thirds of the molecule. The immuno-electroblotting analysis confirms that the pWR234 plasmid expresses a smaller NusA protein. These results mean that the essential recognition sites for other macromolecules on the 
NusA protein are likely to be located in the amino two-thirds of the protein. However, we cannot exclude the possibility that carboxy-terminal activity is provided to the truncated protein by the presence of the NusA1 or NusAcs10 proteins in these merodiploids.

In comparing the activities of the NusA products from E. coli and S.typhimurium, only the difference in the ability to facilitate the action of $\lambda$ $\mathrm{pN}$ appears to be significantly different; NusA ${ }^{\text {sal }}$ can function in $E$. coli growth and support the action of the $\mathrm{pN}$-analogs of lambdoid phages 21 and P22. Our sequence analysis of the Salmonella nusA gene and comparison with $E$. coli nusA identifies three segments of heterogeneity between the amino portions of the two proteins (unpublished results). We suggest that these domains may be important sites for these interactions. Computer analysis fails to uncover any significant conformational difference in the structure of the two proteins. Therefore, it is likely that these amino acid heterogeneities represent actual sites of interaction rather than sites that alter secondary or tertiary protein structure (which might lead to abortive interactions at other sites).

\section{(b) $\lambda p N$ interacts with $P 22$ nut $R$}

It has been suggested that the recognition element for $\mathrm{pN}$ in the nut region is the sequence of dyad symmetry (Salstrom \& Szybalski, 1978). The isolation by Salstrom \& Szybalski of the nut $\mathrm{L}$ mutation in the center region of the dyad demonstrates the importance of this sequence or structure to the $N$ reaction. The reason for suspecting that the dyad symmetry may be a target for $\mathrm{pN}$ (Friedman \& Gottesman, 1983) was based primarily on two observations: first, $\lambda \mathrm{pN}$ appeared to be specific for its own nut region, e.g. $\lambda$ cannot complement a phage $21 \mathrm{~N}^{-}$(Friedman et al., 1973b) or P22 24- phage (Hilliker \& Botstein, 1976); and second, there are significant differences in the nut dyad symmetries from the different phages which could explain nut-pN specificity for the different lambdoid phages.

The observation reported in this paper, that $\lambda \mathrm{pN}$ can complement a P22 $\mathrm{N}^{-}$(gene 24) mutant shows that an argument for strict exclusivity in $\mathrm{pN}$ action cannot be true. In fact, the earlier work of Hilliker $\&$ Botstein (1976) showing that P22 pN can substitute for $\lambda \mathrm{pN}$ elegantly made this argument for the 24 gene product of P22. These observations do not rule out the regions of dyad symmetry as recognition sites for the different $N$ products. There is clearly more efficient antitermination activity when a nut site interacts with its cognate $\mathrm{pN}$. In addition, as pointed out by $\mathbf{J}$. Greenblatt (personal communication), there are conserved sequences within the different nut dyad symmetries which could explain the partial activity of $\mathrm{pN}$ proteins for heterologous nut sequences.

\section{(c) boxA1 enhances $\lambda$ growth in the nus $A 1$ host}

Although there are $n u t$ regions downstream from both $p \mathrm{~L}$ and $p \mathrm{R}$, the nut region downstream from $p \mathbf{R}$ has primary influence over expression of genes that play essential roles in lytic phage growth. This explains why a change in the boxA sequence of nut $\mathrm{L}$ (e.g. box $\mathrm{Al}$ ) is not necessary to facilitate $\lambda$ growth in a NusA $A^{\text {Sal }}$ host. We have separated the $n u t R$ region boxAl mutation from the $N$ (pun) mutations. Although the boxAl mutation was selected to enliance $\lambda$ growth with the Salmonelle NusA protein, it also facilitates $\lambda$ growth in the $E$. coli nusAl host, even in the absence of the $N$ (pun) mutations (Table 5). This indicates that the boxAl mutation does not specifically enhance the ability of NusA $^{\text {sal }}$ to operate with $\lambda \mathrm{pN}$, but rather suggests that it is a change resulting in a more effective box $\mathrm{A}$ sequence.

The fact that $\lambda N^{+} b o x \mathrm{Al}$ grows on the nusE71 host as well as nusAl (but not nusB5 or nus $\mathrm{C60}$ ) calls into question the idea that the boxA site is specific for NusA protein. However, several lines of evidence support the idea that boxAl may improve some type of signal between box A and NusA. First, a number of mutations that suppress nusAl for $\mathrm{pN}$ action also suppress $n u s \mathrm{E} 71$, including changes in $n u s \mathrm{~B}$ as well as in $N$ (Ward et al., 1983; Schauer, 1985). Therefore, it might not be surprising that NusA activity facilitated by mutant boxA could suppress the effect of the nusE7l mutation. Second, when a strong $\rho$-dependent termination signal is placed downstream from the nut region (r32-IS2; Table 5), the new $\lambda$ boxAl derivative does not form plaques on the nusE7l host. Thus, the enhanced growth of $\lambda b o x \mathrm{Al}$ in the nusE7l mutant may merely reflect a more optimal NusA-boxA interaction. Third, $\lambda p u n A 1$, which was selected to grow on the nusAl host, plates equally well on nusE71 (Table 5). However, $\lambda p u n A l$ exhibits the same behavior as $\lambda b o x \mathrm{Al}$ when the r32-IS2 termination signal is inserted; growth on the nusE71 host is abolished. Thus, the stronger terminator prevents $\lambda$ growth on nusE71 in the case of an enhanced $\mathrm{pN}$-NusA interaction in the same manner as in the case of a postulated boxAl-NusA recognition.

Additional evidence that three $\mathrm{T}$ residues in box $\mathrm{A}$ are more optimal than two derives from the studies with $\mathrm{NusA}^{\mathrm{Sal}}$. Provided that there is punAl,133 mutant $\mathrm{pN}$ present, $\lambda$ boxAl will grow well in the NusA ${ }^{\text {Sal }}$ host. However, even in the presence of the punAl,133 pN, $\lambda$ with a wild-type boxA sequence grows very poorly. But if NusA ${ }^{\mathrm{Sal}}$ protein is supplied in excess (with pNAS1000), גpunA1,133 box $\mathrm{A}^{+}$will also grow. We suggest that the ability of $\mathrm{NusA}^{\text {Sal }}$ to function with the wild-type boxA means that the three $\mathrm{T}$ residues in box $\Lambda 1$ (CGCTCTTT) do not represent a qualitatively different box $\mathrm{A}$, but rather a more optimal box $\mathrm{A}$ sequence for $\mathrm{NusA}^{\text {Sal }}$. Thus, the experiments with both the mutant $E$. coli NusA and the natural Salmonella variant point to the box $\mathrm{A}$ sequence with three $\mathrm{T}$ residues as a generally more optimal site. Moreover, the fact that 
increased levels of NusA product enhance the $N$ antitermination reaction strongly argues that NusA is specifically required for the $N$-imposed antitermination. This does not rule out a role for NusA in terminating transcription. NusA could be multifunctional, participating in antagonistic reactions depending on the nature of the other participants.

Finally, we wish to stress that although these genetic studies provide additional support for the idea that boxA might play some role in NusA recognition, we have no direct proof that box $\mathrm{A}$ is a binding site. It is possible that the NusA-boxA interaction is indirect; we do not exclude the possibility that the recognition events could take place via an intermediary, such as another Nus protein. Binding studies carried out by Tsugawa et al. (1985) indicate that NusA associates in vitro with a site on the RNA immediately upstream from boxA. It is not unlikely that the nearby boxA sequence participates in this association. However, the binding sequence reported by the authors is not present in $\lambda p \mathrm{~L}$ operon

We thank the following for their help: Drew Granston for many discussions; Dave McGrath for assistance with some experiments; Jack Greenblatt and Bob Landick for purified NusA protein; Rod Nairn and Richard Smith for help with Western gels; Lathe Claflin for preparation of immune serum; Dale Oxender for romputer analysis of NusA secondary structure; Mike Savageau for help in designing the selection for the arga:: Tno mutant; Phil Youderian for suggesting the protocol for selecting $\lambda n u s \mathrm{~A}^{\mathrm{Sal}}$ and for providing the Salmonella bank. This work was supported by grants from the National Institutes of Health to D.I.F.

\section{References}

Adhya. S., Gottesman, M. \& de Crombrugghe, B. (1974). Proc. Nal. Acad. Sci., U.S.A. 71, 2534-2538.

Ames, G. F. \& Nikaido, K. (1976). Biochemistry, 15, 616623 .

Baron, L. S., Penido. E., Ryman, I. R. \& Falkow, S (1970). J. Bacteriol. 102, 221-233.

Biggin, M. D., Gibson. T. J. \& Hong, G. F. (1983). Proc. Nat. Acad. Sci., U.S.A. 80, 3963-3965.

Brachet, P., Eisen, H. \& Rambach, A. (1970). Mol. Gen Genet 108, 266-276.

('aesareni, G., Muesing, M. A. \& Polisky, B. (1982). Proc. Nat. Acad. Sci.. C.S.A. 79, 6313-6317.

('ourt, D). \& Sato, K. (1969). Virology, 39, 348-352.

de Crombrugghe, B. Adhya, S., Gottesman, M. \& Pastan, I. (1973). Nature New Biol. 241, 260-264.

Farnham, P. J., Greenblatt, J. \& Platt, T. (1982). Cell, 29, $945-951$.

Fiandt, M., Hradeena, Z., Lozeron, H. A. \& Szybalski, W (1971). In The Bacteriophage Lambda (Hershey, A. ed.). pp. 329-359, Cold Spring Harbor Laboratory Press, Cold Spring Harbor, NY.

Fisher, R. \& Yanofsky, C. (1983). J. Biol. Chem. 258 9208-9212.

Franklin. N. C. (1974). J. Mol. Biol. 89, 33-48.

Franklin. N. (. (1985). J. Mol. Biol. 181, 85-91.

Franklin. N. C. \& Bennett. G. N. (1979). Gene, 8, 107119.
Friedman, D. I. (1971). In The Bacteriophage Lambda (Hershey, A. D., ed.), pp. 733-738, Cold Spring Harbor Laboratory Press, Cold Spring Harbor, NY.

Friedman, D. I. \& Baron, L. S. (1974). Virology, 58, 141148.

Friedman, D. I. \& Gottesman, M. (1983). In Lambda II (Hendrix, R., Roberts, J. W., Stahl, F. W. \& Weisberg, R. A., eds), pp. 21-51, Cold Spring Harbor Laboratory Press, Cold Spring Harbor, NY.

Friedman, D. I. \& Olson, E. R. (1983). Cell, 34, 143-149

Friedman, D. I., Jolly, C. T. \& Mural, R. J. (1973a) Virology, 51, 216-226.

Friedman, D. I., Wilgus, G. S. \& Mural, R. J., (1973b) J. Mol. Biol. 81, 505-516.

Friedman, D. I., Schauer, A. T., Baumann, M. R., Baron, L. S. \& Adhya, S. (1981). Proc. Nat. Acad. Sci. U.S.A. 78, $1115-1119$

Greenblatt, J. \& Li, J. (1981). Cell, 24, 421428.

Greenblatt, J. \& Li, J. (1982). J. Biol. Chem. 257, 362365.

Greenblatt, J., McLimont, M. \& Hanly, S. (1981). Nature (London), 292, 215-220.

Hilliker, S. \& Botstein, D. (1976). J. Mol. Biol. 106, 537566.

Hilliker, S., Gottesman, M. \& Adhya, S. (1978). Virology $86,37-47$.

Hong, J.-S. \& Ames, B. N. (1971). Proc. Nat. Acad. Sci. U.S.A. 68, 3158-3162.

Ishii, S., Ihara, M., Maekawa, T., Nakamura, Y., Uchida H. \& Immamoto, F. (1984). Nucl. Acids Res. 12, $3333 \quad 3342$

Karn, J., Brenner, S., Barnett, L. \& Caesareni, G. (1980). Proc. Nat. Acad. Sci., U.S.A. 77, 5172-5176.

Kingston, R. E. \& Chamberlin, M. J. (1981). Cell, 27. $523-531$.

Lau, L., Roberts, J. W. \& Wu, R. (1982), Proc. Nat. Acad. Sci., U.S.A. 79, 6171-6175.

Liedke-Kulke, M. \& Kaiser, A. D. (1967). Virology, 32 $465-474$

Maniatis, T., Fritsch, E. F. \& Sambrook, J. (1982). Molesular Cloning, A Laboratory Manual, Cold Spring Harbor Laboratory Press, Cold Spring Harbor, NY.

McClure, W. R., Hawley, D. K. \& Malan, T. P. (1982). In Promoters: Structure and Function (Rodriguez, R. L. \& Chamberlin, M. J., eds), pp. 111-120, Praeger Press, New York.

Messing, J. (1983). Methods Enzymol 101, 20-78.

Miller, H. I. \& Friedman, D. I. (1980). Cell, 20, 711-719.

Miller, H. I., Mozola, M. A. \& Friedman, D. I. (1980) Cell, 20, 721-729.

Nakamura, Y. \& Mizusawa, S. (1985). EMBO I. 4, 527 532

Nakamura, Y., Mizusawa, S., Court, D. L. \& Tsugawa, A (1986). J. Mol. Biol. 189, 103-112

Olson, E. R., Tomich, C.-S. C. \& Friedman, D. I. (1984) J. Mol. Biol. 180, 1053-1064.

Peacock, S., Lupski, J. R., Godson, G. N. \& Weissbach H. (1985). Gene, 33, 227-234.

Peltz, S. W., Brown, A. L., Hasan, N., Podhajska, A. J \& Szybalski, W. (1985). Science, 228, 91-93.

Roberts, J. W. (1969) Nature (London), 244, 1168-1174.

Salstrom, J. S. \& Szybalski, W. (1978). J. Mol. Biol. 124, $195-221$

Sanger, F., Coulson, R. A., Hong, G. F., Hill, D. F. \& Peterson, G. B. (1983). J. Mol. Biol. 162, 729-773.

Schauer, A. T. (1985). Ph.D. thesis, University of Michigan. Ann Arbor.

Schmidt, M. C. \& Chamberlin, M. J. (1984). Biochemistry, 23. $197-203$. 
Sharrock, R. A., Gourse, R. L. \& Nomura, M. (1985). Proc. Nat. Acad. Sci., U.S.A. 82, 5275-5279.

Simons, R. W. \& Kleckner, N. (1983). Cell, 34, 683-691. Szybalski, E. \& Szybalski, W. (1979). Gene, 7, 217-270.

Tomlich, P. K. \& Friedman, D. I. (1977). In DNA Insertion Elements, Plasmids and Episomes (Bukhari, A. I., Shapiro, J. A. \& Adhya, S. L., eds), pp. 99-107, Cold Spring Harbor Laboratory Press, Cold Spring Harbor, NY.
Towbin, H., Staehelin, R. \& Gordon, J. (1979). Proc. Nat. Acad. Sci., U.S.A. 76, 4350-4354.

Tsugawa, A., Kurihara, T., Zuber, M., Court, D. \& Nakamura, Y. (1985). EMBO J. 4, 2337-2342.

Vieira, J. \& Messing, J. (1982). Gene, 19, 259-263.

Ward, D. F., DeLong, A. \& Gottesman, M. E. (1983). J. Mol. Biol. 168, 73-86.

Edited by M. Gottesman 